\title{
Predictors of Complementary and Alternative Medicine Use by Yoruba and Hausa People in Urban Slum Areas of Ibadan, Nigeria
}

\author{
Chinyerem C. Nwachukwu ${ }^{1 *}$, Amaechi C. Nwachukwu², Ayodeji M. Adebayo ${ }^{3}$, Akinola \\ A. Fatiregun ${ }^{4}$, Eme T. Owoaje ${ }^{3}$ \\ ${ }^{1}$ Department of Community Medicine, Chukwuemeka Odumegwu Ojukwu University, Awka, Nigeria \\ ${ }^{2}$ Department of Surgery, Chukwuemeka Odumegwu Ojukwu University, Awka, Nigeria \\ ${ }^{3}$ Department of Community Medicine, University of Ibadan, Ibadan, Nigeria \\ ${ }^{4}$ World Health Organization, Nigeria Country Office, Ondo State
}

*Corresponding Author: Chinyerem C. Nwachukwu, Department of Community Medicine, Chukwuemeka Odumegwu Ojukwu University, Awka, Nigeria, Email: chinyeremcynthia@yahoo.com

\begin{abstract}
Background: Alternative medicine is the fundamental method used by people to preserve their health and prevent diseases. It is also an alternative for those who live far from medical facilities in places where there are no physicians. Even where there are physicians, many people still take the lead in their own health care. This study determined the predictors of CAM use among two ethnic groups and document reasons for their choices.

Methods: A comparative cross-sectional study using the WHO modified cluster sampling technique to select 400 respondents from each of the two study groups (Yoruba and Hausa ethnic groups) in Ibadan North Local Government Area of Oyo State, Nigeria. Questionnaire was used to collect information on sociodemographic characteristics, use of CAM and reasons for use.

Results: Current CAM use was reported by $75.0 \%$ of Yoruba and $88.0 \%$ of Hausa $(p<0.05)$. The main reasons given for CAM use were belief in the practitioner, perceived efficacy and availability. The predictors of current CAM use were being currently married [OR 2.77; 95\% CI 1.49 - 5.16], Islamic religion [OR 2.70; 95\% CI 1.35 - 5.41] and Hausa ethnicity [OR 1.38; 95\% CI 1.00 - 2.13].
\end{abstract}

Conclusion: Influence of other individuals in the community, advertisement, and easy accessiblility of CAM are major contributory factors to CAM use.

Keywords: Complementary, alternative, medicine, predictors, reasons, use.

Abbreviations: Complementary and Alternative Medicine (CAM)

\section{INTRODUCTION}

Our current medical knowledge is derived from man's cumulative experience from primitive to present times. Modern medicine is what it is today because it has drawn knowledge from the traditional cultures of different people and societies, over a long period of time [1].

The most common reason for using CAM as reported by homeless youth attending a free clinic in America was because it was natural and organic $(43.9 \%)$. Other reasons included low cost (28\%), perceived efficacy (26.1\%), negative experiences with physicians $(24.2 \%)$, friends use CAM and recommended it (20\%), and pervasive mistrust of physicians (19\%) [2]. Family practice patients in America gave similar reason for CAM use [3].

Pressure of elders, family members, friends and neighbours were among the reasons why people used CAM for children with chronic conditions in Lagos, Nigeria [4]. There was also the cultural beliefs that illnesses have a 'spiritual' origin and people are interested in finding the root cause of their problems and therefore consult with alternative practitioners [5]. 
A community-based study among low-income women in Uyo, Akwa-Ibom State, Nigeria showed that in the face of "stock out" where most drugs, pharmaceuticals, and medical supplies are consistently not available for dispensing in public hospitals and health centers, these poor urban women resorted to alternative health care in prayer houses, herbal homes, patent medicine vendors, health workers homes, and traditional birth attendants. The study reported that stock out in government health facilities resulted in health hazards and the relapse of illnesses as a result of nonadherence to treatment regime and exposure to fake, expired, and adulterated drugs [6].

For respondents in a community-based study in Lagos State, Nigeria, perceived efficacy of herbs in treating malaria episodes featured as the major reason for their use as claimed by the majority $(>50 \%)$ of the respondents in each of the ethnic groups studied, while cost consideration was the next most important factor. Other factors mentioned are the absence of side effect in herbal medicine and to avoid the itching side effect and ineffectiveness of chloroquine and some other anti-malarial drugs [7]. In Benin City, Nigeria, traditional birth attendants administered herbs orally for the treatment of abdominal pain, absence of foetal movement, excessive vaginal discharge, headache, dizziness, fever and retained placenta. In addition to oral herbs, bathing with herbs was also prescribed for threatened abortion. Infertility problem was treated with herbs or by performing rituals, while oracle is consulted for bad dreams [8].

The majority of respondents in a study done in America used unconventional therapy for chronic, as opposed to life-threatening, medical conditions [9]. A third of the respondents in study conducted in Osogbo, Nigeria believed that rabies infection can be treated with herbs. Of the 387 victims of dog bite, 240 (62\%) never sought prophylactic post-exposure treatment in a health facility [10].

Sources of information about CAM included the media: television, radio and newspaper advertisements (13\%); CAM practitioners (5\%); churches (2\%); open market advertisements (2\%); and hospital staff (1\%) [4]. Respondents in a community-based study in Australia obtained information on CAM from CAM practitioners. The internet and health food shops served as the least useful source of information [11]. Fifty seven percent of CAM providers reported attending educational programmes on dietary supplement, while the use of supplements by patients was most influenced by advertisements (40\%) and friends (40\%) [12].

A review of 19 surveys conducted between 1982 and 1995 that examined the practices and beliefs of conventional physicians with regard to five of the more prominent CAM therapies showed that acupuncture had the highest rate of physician referral, 43\%, among the five CAM therapies; followed by chiropractic, $40 \%$, and massage (21\%). Rates of CAM practice by conventional physicians varied from as low of $9 \%$ for homeopathy to a high of $19 \%$ for chiropractic and massage therapy. Approximately half of the surveyed physicians believed in the efficacy of acupuncture $(51 \%)$, chiropractic (53\%), and massage $(48 \%)$, while fewer believed in the value of homeopathy (26\%) and herbal approaches $(13 \%)$. The review suggested that large numbers of physicians are either referring to or practicing some of the more prominent and well-known forms of CAM and that many physicians believe that these therapies are useful or efficacious [13].

Various factors have been found to be associated with the use of CAM. CAM use in America was greatest among women, people aged 30-69, those with higher levels of education and higher incomes, American Indians/Alaska native, whites and Asians than among blacks and Hispanics [14]. The frequency of use of unconventional therapy, in a study done in America, varied somewhat among sociodemographic groups, with the highest use reported by nonblack persons from 25 to 49 years of age who had relatively more education and higher incomes [9].

Use of alternative medicine among patients with Parkinson's disease was commoner among the younger age group $(\mathrm{p}=0.002)$, patients who had higher income $(\mathrm{p}=0.038)$ and higher education level $(\mathrm{p}=0.006)$ [15]. A similar result was found in another study done among patients who were about to undergo surgery in America, where women and patients aged 40-60 years were more likely to use herbal medicines. Overthe-counter medication use was also strongly associated with herbal preparation use [16]. No significant association was found between CAM use and age, gender, educational level and race among family practice patients in America [3]. Among patients attending gastroenterology clinic in Carlifornia, USA, there were no significant differences between alternative 
medicine users and nonusers in sociodemographic characteristics [17].

A national survey done in America to determine why patients use alternative medicine showed predictors of alternative health care use to be: more education, poorer health status, a holistic orientation to health, having had a transformational experience that changed the person's worldview, any of the following health problems: anxiety, back problems, chronic pain, urinary tract problems; and classification in a cultural group identifiable by their commitment to environmentalism, commitment to feminism, and interest in spirituality and personal growth psychology. Dissatisfaction with conventional medicine did not predict use of alternative medicine. Only $4.4 \%$ of those surveyed reported relying primarily on alternative therapies [18].

Factors that were positively associated with child CAM use in America included parents' use of CAM $(\mathrm{p}<.0001)$; greater parent age $(\mathrm{p}=$ $0.0005)$, greater child age $(\mathrm{p}=.001)$, and complaints of frequent respiratory illnesses, asthma, headaches, and nosebleeds. Ethnicity and parental education were not associated with child CAM use [19]. Elderly CAM users in America tended to be younger, more educated, reported having either arthritis and/or depression/anxiety, not hypertensive, engage in exercise, meditation, and make more frequent physician visits. Use of CAM was not associated with any observed changes in health status [20]. Another study among the elderly in American showed that CAM use correlated most strongly with female gender $(p<0.0001)$, greater education $(\mathrm{p}=0.010)$, thyroid disease $(\mathrm{p}$ $=0.019)$ and arthritis $(\mathrm{p}=0.025)$. There was no correlation with income, race, age, or selfperceived health status [21].

Use of herbs during pregnancy, as found by a hospital-based study in America, was strongly associated with prior use of herbal supplements $(25.6 \%$ versus $1.2 \%) \mathrm{p}<0.001$. There was greater use among white women $(11.4 \%$ versus $6.1 \%$ in other racial groups) and women with at least college-level education $(10.1 \%$ versus $7.6 \%$ for high school or less). No association was found between herb use during pregnancy and age or income level [22]. In a household survey in America, individuals with diabetes were 1.6 times more likely to use CAM than individuals without diabetes (8\% versus $5 \%, \mathrm{p}<$ $0.0001)$. Also estimates of CAM use were not significantly different across selected chronic medical conditions, but diabetes was an independent predictor of CAM use. Among individuals with diabetes, older age ( $\geq 65$ years) and higher educational attainment (high school education or higher) were independently associated with CAM use [23].

A higher proportion of non-Hispanic whites (39\%) used CAM for a mental or substance use disorder than either African Americans (24\%) or black Caribbeans (12\%) in Michigan. This pattern occurred both when those who used only prayer and other spiritual practices were omitted and when they were included, as well as when the use of CAM only was examined. In the latter two instances, however, the magnitude of difference among the three groups declined. In contrast, when different CAM modalities were examined among CAM users, a smaller proportion of whites reported using prayer and other spiritual practices (47\%) than African Americans (63\%) and black Caribbeans (68\%). The use of herbal therapy was highest among black Caribbeans (31\%), followed by whites (28\%) and African Americans (15\%). A higher proportion of African Americans reported using spiritual healing by others (18\%) than either black Caribbeans $(13 \%)$ or whites $(9 \%)$. A higher proportion of adults aged 30-54 years (38\%) used CAM than younger (32\%) and older (28\%) adults, and females were more likely than males to use CAM (39\% versus 28\%). The proportion using CAM increased with higher levels of education, from $19 \%$ of respondents with less than a high school education to $52 \%$ of those with a college degree or higher. A slightly higher proportion of respondents who were working at the time of the interview used CAM (37\%) than those who were not working (30\%). CAM use also increased with income, from $27 \%$ of those in the lowest income group to $47 \%$ of those in the highest [24].

Cancer patients in many European countries revealed that the profile of the CAM user was that of younger people, female and with higher educational level [25] CAM users in Australia were more likely to be female, be better educated, have a higher income, and be employed. Females were also using significantly more herbal medicines, ginseng, Chinese medicines, and aromatherapy oils. Many of the medicines were self-prescribed [26].

A greater proportion of the respondents above the age of 40 years in South Africa preferred CAM [27]. Use of most types of CAM by 
American women differed significantly by race/ethnicity in a multi-site, multi-ethnic study, except for the use of ginkgo biloba and glucosamine. Significantly more African Americans at most sites and Chinese women used ginseng [28]. CAM use was greater in males than in females cancer patients in Enugu but was not affected by age, marital status, level of education, religious affiliation, or socioeconomic status [29]. A difference in health-seeking behaviour was found between Yoruba and Fulani residents in a rural area of Oyo State, Nigeria. Fulani residents were more likely to use private facilities during a recent illness, while Yoruba residents more commonly used government facilities [30]. There was no difference in the clinical characteristics, socioeconomic status, and blood pressure control of CAM users and non-users among hypertensive patients in Lagos. Patients who utilized CAM had higher BMI compared with those who did not, but the difference was not statistically significant (mean BMI \pm SD of $29.1 \pm 5.6$ vs $\left.27.1 \pm 5.9 \mathrm{~kg} / \mathrm{m}^{2} ; \mathrm{P}=0.05\right)$ [31].

A study done among 156 traditional healers/midwives in the Yoruba-speaking areas of Nigeria revealed that $72.4 \%$ of them were more than 40 years old. The study also revealed that all traditional healers/midwives were trained before they started to practise, and that people from all walks of life, irrespective of their educational and socio-economic status, illiterates, literates, students, traders, top professionals, nurses, doctors and clergymen consult traditional healers for diverse reasons. Some herbalists specialized in different areas, others are general practitioners. More than 50\% of the herbalists earn enough from their practice for their upkeep. Patients pay for their treatment in cash or in kind. One hundred and twenty five $(80 \%)$ of the herbalists were willing to cooperate with western-trained doctors if this is suggested [32].

\section{Materials ANd Methods}

\subsection{Study Area}

The study was done in Ibadan North Local Government Area (IBNLGA), Oyo State, Nigeria. The inhabitants are mainly Yorubas. Two wards within the study area, Sabo, inhabited predominantly by Hausa people, and Inalende, inhabited predominantly by Yoruba people were purposively selected and used for the study. Some of the inhabitants have no formal education and belong to the low socio- economic class. The area is an urban slum characterised by limited access to pipe borne water, irregular supply of electricity and overcrowding.

\subsection{Study Population}

The Yoruba and Hausa adults who were aged 18 years and above.

\subsection{Study Design}

Comparative, cross-sectional study design.

\subsection{Sample Size Determination}

The sample size was calculated using the formula for comparing two independent groups [33]:

$$
\mathrm{N}=\frac{2\left(\mathrm{Z}_{\underline{\alpha}}+\frac{\left.\mathrm{Z}_{\beta}\right)^{2} \mathrm{P}_{0}}{\mathrm{~d}^{2}}\left(1-\mathrm{P}_{0}\right)\right.}{\mathrm{P}}
$$

where $\mathrm{N}=$ minimum sample size

$\mathrm{P}_{0}=$ mean prevalence of CAM use in the 2 comparison groups i.e. $\left(\mathrm{P}_{1+} \mathrm{P}_{2}\right) / 2$

$$
\frac{\mathrm{P} 1+\mathrm{P} 2}{2}=\frac{0.69+0.47}{2}=0.58
$$

$\mathrm{P}_{1}=0.69$. Previous estimate of CAM use among Yoruba population [7].

$\mathrm{P}_{2}=0.47$. Previous estimate of CAM use among Hausa population [7].

$\mathrm{d}=$ Difference between $\mathrm{P}_{1}$ and $\mathrm{P}_{2}=0.22$

$\mathrm{Z}_{\alpha}=$ Standard normal deviate corresponding to the probability $\alpha$, i.e. the probability of making a type 1 error at $5 \%=1.96$.

$\mathrm{Z}_{\beta}=$ the standard normal deviate at $80 \%$ statistical power, corresponding to the probability of making a type 2 error $=0.84$

$$
\mathrm{N}=387
$$$$
\mathrm{N}=\underline{2(1.98+0.84)^{2} 0.58(1-0.58)}
$$

A total of 400 respondents in each group were studied.

\subsection{Sampling Technique}

The World Health Organization (WHO) modified cluster sampling technique [34] was used. This sampling method was adapted from the WHO 30 by 7 cluster sampling technique, developed by WHO in 1978 for estimating immunization coverage.

A total of 400 questionnaires were administered in each ward. The ward settlements were considered to be clusters and 50 questionnaires were administered in each of the 8 
clusters/settlements in Sabo. In Inalende, 67 questionnnaires were administered in each of the first five clusters and 65 in the sixth cluster.

\subsection{Data Collection}

The questionnaire was pretested in Ojoo in Akinyele LGA of Ibadan, another urban slum area community with Hausa and Yoruba residents. Questionnaires were administered by four trained research assistants, two Hausa speaking and two who could speak Yoruba. Appropriate amendments were made after the pre-test as necessary. Current CAM use refers to use in the last three months.

\subsection{Ethical Consideration}

The Oyo State Ethical Review Committee gave approval for the study. Informed consent was

Table1. Respondents' socio-demographic characteristics obtained from the respondents and participation was voluntary.

\subsection{Data Analysis}

Data was analyzed using SPSS. Chi square test was used to test associations between categorical variables at 5\% level of significance. Multivariate analysis was done with binary logistics regression. Variables included in the enter method were those that were found to be significant from bivariate analysis at $p \leq 0.2$, as well as factors that have been shown by other literature to be associated with CAM use. Predictors were those significant at $\mathrm{p}=0.05$.

\section{RESUltS}

\begin{tabular}{|c|c|c|c|c|c|}
\hline $\begin{array}{l}\text { Socio-demographic } \\
\text { characteristics }\end{array}$ & $\begin{array}{l}\text { Yoruba } \\
\mathrm{N}=400 \\
\mathrm{n}(\%)\end{array}$ & $\begin{array}{l}\text { Hausa } \\
\mathrm{N}=400 \\
\mathrm{n}(\%)\end{array}$ & $\begin{array}{l}\text { Total } \\
\mathbf{N}=\mathbf{8 0 0} \\
\mathrm{n}(\%)\end{array}$ & $\begin{array}{l}\text { Statistics } \\
\chi^{2}\end{array}$ & p-value \\
\hline $\begin{array}{c}\text { Age group (years) } \\
\leq 24 \\
25-34 \\
35-44 \\
\geq 45 \\
\text { Mean age }( \pm \mathrm{SD}) \text { years }\end{array}$ & $\begin{array}{l}40(10.0) \\
150(37.4) \\
75(18.8) \\
135(33.8) \\
40.1( \pm 15.8)\end{array}$ & $\begin{array}{l}119(29.8) \\
137(34.2) \\
70(17.5) \\
74(18.5) \\
32.6( \pm 12.8)\end{array}$ & $\begin{array}{l}159(19.9) \\
287(35.9) \\
145(18.1) \\
209(26.1) \\
36.4( \pm 14.9)\end{array}$ & $\begin{array}{l}57.817 \\
7.360 * *\end{array}$ & $\begin{array}{l}<0.001 * \\
<0.001 *\end{array}$ \\
\hline $\begin{array}{ll}\text { Sex } & \\
& \text { Male } \\
& \text { Female }\end{array}$ & $\begin{array}{l}165(41.2) \\
235(58.8)\end{array}$ & $\begin{array}{l}209(52.2) \\
191(47.8)\end{array}$ & $\begin{array}{l}374(46.8) \\
426(53.2)\end{array}$ & 9.721 & $0.002 *$ \\
\hline $\begin{array}{c}\text { Level of education } \\
\text { No formal } \\
\text { Primary } \\
\text { Secondary } \\
\text { Tertiary }\end{array}$ & $\begin{array}{l}59(14.8) \\
97(24.2) \\
210(52.5) \\
34(8.5)\end{array}$ & $\begin{array}{l}95(23.8) \\
106(26.5) \\
187(46.7) \\
12(3.0)\end{array}$ & $\begin{array}{l}154(19.2) \\
203(25.4) \\
397(49.6) \\
46(5.8)\end{array}$ & 1.081 & $<0.001 *$ \\
\hline $\begin{array}{l}\text { Marital status } \\
\text { Currently married } \\
\text { Not currently } \\
\text { married }\end{array}$ & $\begin{array}{l}306(76.5) \\
94(23.5)\end{array}$ & $\begin{array}{l}243(60.8) \\
157(39.2)\end{array}$ & $\begin{array}{l}549(68.6) \\
251(31.4)\end{array}$ & 23.042 & $<0.001 *$ \\
\hline $\begin{array}{c}\text { Religion } \\
\text { Christianity } \\
\text { Islam } \\
\end{array}$ & $\begin{array}{l}191(47.8) \\
209(52.2) \\
\end{array}$ & $\begin{array}{l}6(1.6) \\
394(98.4) \\
\end{array}$ & $\begin{array}{l}197(24.6) \\
603(75.4) \\
\end{array}$ & 2.413 & $<0.001 *$ \\
\hline $\begin{array}{l}\text { Occupation } \\
\text { Professional \& skilled } \\
\text { Partly skilled } \\
\text { Unskilled } \\
\end{array}$ & $\begin{array}{l}142 \quad(35.5) \\
224(56.0) \\
34(8.5)\end{array}$ & $\begin{array}{l}86(21.5) \\
254(63.5) \\
60(15.0)\end{array}$ & $\begin{array}{l}228(28.4) \\
478(59.8) \\
94(11.8)\end{array}$ & 22.829 & $<0.001 *$ \\
\hline $\begin{array}{r}\text { Monthly income } \\
< \pm 10,000 \\
\geq \$ 10,000 \\
\end{array}$ & $\begin{array}{l}245(61.2) \\
155(38.8)\end{array}$ & $\begin{array}{l}269(67.2) \\
131(32.8)\end{array}$ & $\begin{array}{l}514(64.2) \\
286(35.8)\end{array}$ & 3.135 & 0.077 \\
\hline
\end{tabular}

*Statistically significant

$* *$ t-test 
Predictors of Complementary and Alternative Medicine Use by Yoruba and Hausa People in Urban Slum Areas of Ibadan, Nigeria

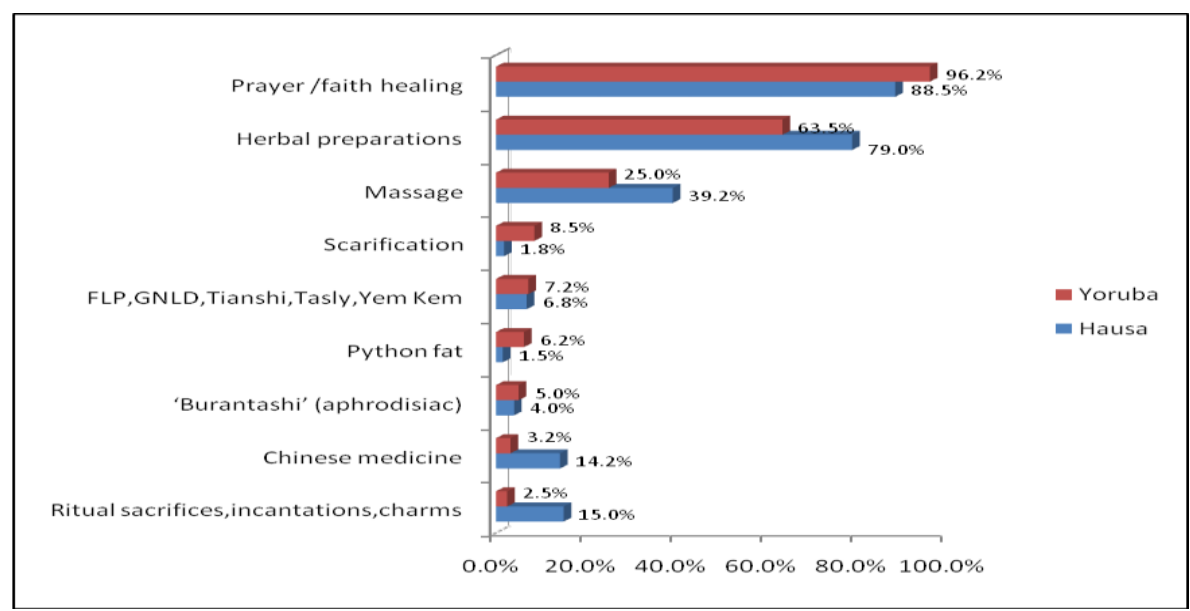

Figure1. Current use of CAM (including prayer/faith healing)

Table2. Reasons for using CAM

\begin{tabular}{|c|c|c|c|c|c|}
\hline Reasons for CAM use & $\begin{array}{l}\text { Yoruba } \\
\text { n }(\%)\end{array}$ & $\begin{array}{l}\text { Hausa } \\
\text { n (\%) }\end{array}$ & $\begin{array}{l}\text { Total } \\
\text { n }(\%)\end{array}$ & $\begin{array}{l}\text { Statistics } \\
\chi 2\end{array}$ & p-value \\
\hline & $(n=354)$ & $(n=383)$ & $(n=737)$ & & \\
\hline $\begin{array}{l}\text { Belief in the practitioner } \\
\text { Yes } \\
\text { No }\end{array}$ & $\begin{array}{l}47(13.3) \\
307(86.7)\end{array}$ & $\begin{array}{l}51(13.3) \\
332(86.7)\end{array}$ & $\begin{array}{l}98(13.3) \\
639(86.7)\end{array}$ & 0.000 & 0.988 \\
\hline $\begin{array}{l}\text { More effective than } \\
\text { modern medicine } \\
\text { Yes } \\
\text { No }\end{array}$ & $\begin{array}{l}24(6.7) \\
330(93.3)\end{array}$ & $\begin{array}{l}71(18.5) \\
312(81.5)\end{array}$ & $\begin{array}{l}95(12.9) \\
642(87.1)\end{array}$ & 22.651 & $<0.001 *$ \\
\hline $\begin{array}{l}\text { Readily available } \\
\text { Yes } \\
\text { No }\end{array}$ & $\begin{array}{l}4(1.1) \\
350(98.9)\end{array}$ & $\begin{array}{l}64(16.7) \\
319(83.3)\end{array}$ & $\begin{array}{l}68(9.2) \\
669(90.8)\end{array}$ & 53.319 & $<0.001 *$ \\
\hline 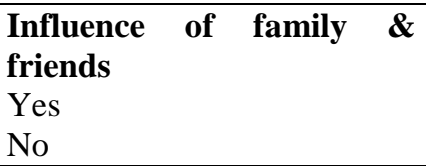 & $\begin{array}{l}18(5.1) \\
336(94.9)\end{array}$ & $\begin{array}{l}17(4.4) \\
366(95.6)\end{array}$ & $\begin{array}{l}35(4.7) \\
702(95.3)\end{array}$ & 0.170 & 0.680 \\
\hline $\begin{array}{l}\text { Tradition/culture } \\
\text { Yes } \\
\text { No }\end{array}$ & $\begin{array}{l}10(2.8) \\
344(97.2)\end{array}$ & $\begin{array}{l}18(4.7) \\
365(95.3)\end{array}$ & $\begin{array}{l}28(3.8) \\
708(96.2)\end{array}$ & 1.769 & 0.183 \\
\hline $\begin{array}{l}\text { Cures diseases of spiritual } \\
\text { origin } \\
\text { Yes } \\
\text { No }\end{array}$ & $\begin{array}{l}11(3.1) \\
343(96.9)\end{array}$ & $\begin{array}{l}14(3.7) \\
369(96.3)\end{array}$ & $\begin{array}{l}25(3.4) \\
712(96.6)\end{array}$ & 0.169 & 0.681 \\
\hline $\begin{array}{l}\text { Cheapness of CAM/high } \\
\text { cost of hospital care } \\
\text { Yes } \\
\text { No }\end{array}$ & $\begin{array}{l}8(2.3) \\
346(97.7)\end{array}$ & $\begin{array}{l}11(2.3) \\
372(97.7)\end{array}$ & $\begin{array}{l}19(2.6) \\
718(97.4)\end{array}$ & 0.275 & 0.600 \\
\hline $\begin{array}{l}\text { No side effect } \\
\text { Yes } \\
\text { No }\end{array}$ & $\begin{array}{l}8(2.3) \\
346(97.7)\end{array}$ & $\begin{array}{l}9(2.3) \\
374(97.7)\end{array}$ & $\begin{array}{l}17(2.3) \\
720(97.7)\end{array}$ & 0.007 & 0.935 \\
\hline
\end{tabular}

Table3. Respondents' reasons for not using CAM

\begin{tabular}{|c|c|c|c|c|c|}
\hline Reasons & $\begin{array}{l}\text { Yoruba } \\
\mathrm{N}=400 \\
\mathrm{n}(\%)\end{array}$ & $\begin{array}{l}\text { Hausa } \\
N=400 \\
n(\%)\end{array}$ & $\begin{array}{l}\text { Total } \\
\mathbf{N}=\mathbf{8 0 0} \\
\mathbf{n}(\%)\end{array}$ & $\begin{array}{l}\text { Statistics } \\
\chi^{2}\end{array}$ & p-value \\
\hline $\begin{array}{l}\text { Doubtful efficacy } \\
\text { Yes } \\
\text { No } \\
\end{array}$ & $\begin{array}{l}10(2.5) \\
390(97.5)\end{array}$ & $\begin{array}{l}13(3.3) \\
387(96.7)\end{array}$ & $\begin{array}{l}23(2.9) \\
777(97.1)\end{array}$ & 0.403 & 0.526 \\
\hline $\begin{array}{l}\text { Expensive } \\
\text { Yes } \\
\text { No }\end{array}$ & $\begin{array}{l}4(1.0) \\
396(99.0)\end{array}$ & $\begin{array}{l}12(3.0) \\
388(97.0)\end{array}$ & $\begin{array}{l}16(2.0) \\
784(98.0)\end{array}$ & 4.082 & 0.043 \\
\hline
\end{tabular}


Predictors of Complementary and Alternative Medicine Use by Yoruba and Hausa People in Urban Slum Areas of Ibadan, Nigeria

\begin{tabular}{|l|l|l|l|l|l|}
\hline Fear of harmful effect & $4(1.0)$ & $10(2.5)$ & $14(1.8)$ & & \\
Yes & $396(99.0)$ & $390(97.5)$ & $786(98.2)$ & 2.617 & 0.106 \\
No & $5(1.3)$ & $6(1.5)$ & $11(1.4)$ & & \\
\hline Others** & $395(98.7)$ & $394(98.5)$ & $789(98.6)$ & 0.092 & 0.761 \\
Yes & No & & \\
\hline
\end{tabular}

**Others - I have not thought of it, I was not brought up that way.

Table4. Respondents' source of information on CAM

\begin{tabular}{|c|c|c|c|c|c|}
\hline Source of information & $\begin{array}{l}\text { Yoruba } \\
\text { N=400 } \\
\text { n }(\%)\end{array}$ & $\begin{array}{l}\text { Hausa } \\
\mathrm{N}=400 \\
\mathrm{n}(\%)\end{array}$ & $\begin{array}{l}\text { Total } \\
\mathrm{N}=\mathbf{8 0 0} \\
\mathbf{n}(\%)\end{array}$ & $\begin{array}{l}\text { Statistics } \\
\chi^{2}\end{array}$ & p-value \\
\hline $\begin{array}{l}\text { Family members } \\
\text { Yes } \\
\text { No }\end{array}$ & $\begin{array}{l}58(14.5) \\
342(85.5)\end{array}$ & $\begin{array}{l}61(15.3) \\
339(84.7)\end{array}$ & $\begin{array}{l}119(14.8) \\
681(85.2)\end{array}$ & 0.089 & 0.766 \\
\hline $\begin{array}{l}\text { Friends and neighbours } \\
\text { Yes } \\
\text { No }\end{array}$ & $\begin{array}{l}39(9.8) \\
361(90.2) \\
\end{array}$ & $\begin{array}{l}32(8.0) \\
368(92.0)\end{array}$ & $\begin{array}{l}71(8.9) \\
729(91.1) \\
\end{array}$ & 0.757 & 0.384 \\
\hline $\begin{array}{l}\text { Mass media } \\
\text { Yes } \\
\text { No }\end{array}$ & $\begin{array}{l}28(7.0) \\
372(93.0)\end{array}$ & $\begin{array}{l}33(8.3) \\
367(91.7)\end{array}$ & $\begin{array}{l}61(7.6) \\
739(92.4)\end{array}$ & 0.444 & 0.505 \\
\hline $\begin{array}{l}\text { Open } \\
\text { advertisement } \\
\text { Yes } \\
\text { No }\end{array}$ & $\begin{array}{l}26(6.5) \\
374(93.5)\end{array}$ & $\begin{array}{l}24(6.0) \\
376(94.0)\end{array}$ & $\begin{array}{l}50(6.3) \\
750(93.7)\end{array}$ & 0.085 & 0.770 \\
\hline $\begin{array}{l}\text { CAM practitioner } \\
\text { Yes } \\
\text { No }\end{array}$ & $\begin{array}{l}18(4.5) \\
382(95.5)\end{array}$ & $\begin{array}{l}14(3.5) \\
386(96.5)\end{array}$ & $\begin{array}{l}32(4.0) \\
768(96.0)\end{array}$ & 0.521 & 0.470 \\
\hline $\begin{array}{l}\text { Hospital staff } \\
\text { Yes } \\
\text { No }\end{array}$ & $\begin{array}{l}9(2.3) \\
391(97.7)\end{array}$ & $\begin{array}{l}6(1.5) \\
394(98.5)\end{array}$ & $\begin{array}{l}15(1.9) \\
785(98.1)\end{array}$ & 0.611 & 0.434 \\
\hline $\begin{array}{l}\text { Public transport } \\
\text { Yes } \\
\text { No }\end{array}$ & $\begin{array}{l}1(0.3) \\
399(99.7)\end{array}$ & $\begin{array}{l}1(0.3) \\
399(99.7)\end{array}$ & $\begin{array}{l}2(0.3) \\
798(99.8)\end{array}$ & $\begin{array}{l}\text { Fisher's } \\
\text { exact }=0.000\end{array}$ & 1.000 \\
\hline
\end{tabular}

\subsection{Factors Associated With CAM Use}

Table 5 shows the association between respondents' socio-demographic characteristics and current use of CAM among Yoruba people. Older age, male gender, being currently married and Islamic religion were significantly associated with current use of CAM ( $p<0.05)$. Level of education, occupation and income were

Table5. Characteristics of Yoruba respondents associated with current use of CAM

\begin{tabular}{|l|l|l|l|l|}
\hline \multirow{2}{*}{ Factors } & \multicolumn{2}{l|}{\begin{tabular}{l}
\multicolumn{2}{l|}{} \\
Nurrent use of CAM
\end{tabular}} & \multicolumn{2}{l|}{} \\
\cline { 2 - 5 } & Yes n (\%) & No n (\%) & $\chi^{2}$ & p-value \\
\hline Age & $134(70.5)$ & $56(29.5)$ & & \\
$\leq 34$ & $166(79.0)$ & $44(21.0)$ & 3.863 & $0.049^{*}$ \\
$\geq 35$ & & & & \\
\hline Sex & $133(80.6)$ & $32(19.4)$ & & \\
Male & $167(71.1)$ & $68(28.9)$ & 4.708 & $0.030^{*}$ \\
Female & $132(69.1)$ & $59(30.9)$ & & \\
\hline Religion & $168(80.4)$ & $41(19.6)$ & 6.764 & $0.009^{*}$ \\
Christianity & & & & \\
Islam & $123(78.8)$ & $33(21.2)$ & & 0.155 \\
\hline Education & $177(72.5)$ & $67(27.5)$ & 2.018 & \\
No formal/Primary & & & & \\
Secondary/Tertiary & &
\end{tabular}

not found to be associated with current use of CAM.

Older age, female gender, low education, being currently married and occupation were significantly associated with current use CAM ( $\mathrm{p}<0.05$ ) among Hausa respondents as displayed in Table 6. 
Predictors of Complementary and Alternative Medicine Use by Yoruba and Hausa People in Urban Slum Areas of Ibadan, Nigeria

\begin{tabular}{|l|l|l|l|l|}
\hline Marital status & & & & \\
Currently married & $244(79.7)$ & $62(20.3)$ & & \\
Not currently married & $56(59.6)$ & $38(40.4)$ & 15.594 & \\
\hline Occupation & & $29(20.4)$ & & \\
Professional \& skilled & $113(79.6)$ & $61(27.2)$ & & \\
Partly skilled & $163(72.8)$ & $10(29.4)$ & 2.535 & 0.282 \\
Unskilled & $24(70.6)$ & $69(28.2)$ & & \\
\hline Monthly income & & $31(20.0)$ & 3.374 & 0.066 \\
$<10,000$ & $176(71.8)$ & $124(80.0)$ & & \\
$\geq 10,000$ & & & \\
\hline
\end{tabular}

*Statistically significant

Table6. Characteristics of Hausa respondents associated with current use of CAM

\begin{tabular}{|c|c|c|c|c|}
\hline \multirow[t]{2}{*}{ Factors } & \multicolumn{2}{|c|}{$\begin{array}{l}\text { Current use of CAM } \\
\mathrm{N}=400\end{array}$} & \multirow[b]{2}{*}{$\chi^{2}$} & \multirow[b]{2}{*}{ p-value } \\
\hline & $\begin{array}{l}\text { Yes } \\
\text { n }(\%)\end{array}$ & $\begin{array}{l}\text { No } \\
\text { n }(\%)\end{array}$ & & \\
\hline $\begin{array}{l}\text { Age } \\
\leq 34 \\
\geq 35 \\
\end{array}$ & $\begin{array}{l}219(85.5) \\
133(92.4)\end{array}$ & $\begin{array}{l}37(14.5) \\
11(7.6)\end{array}$ & 4.052 & $0.044^{*}$ \\
\hline $\begin{array}{l}\text { Sex } \\
\text { Male } \\
\text { Female }\end{array}$ & $\begin{array}{l}171(81.8) \\
181(94.8)\end{array}$ & $\begin{array}{l}38(18.2) \\
10(5.2)\end{array}$ & 15.839 & $<0.001 *$ \\
\hline $\begin{array}{l}\text { Religion } \\
\text { Christianity } \\
\text { Islam } \\
\end{array}$ & $\begin{array}{l}5(83.3) \\
347(88.1) \\
\end{array}$ & $\begin{array}{l}1(16.7) \\
47(11.9)\end{array}$ & Fisher's exact & 0.736 \\
\hline $\begin{array}{l}\text { Education } \\
\text { No formal/Primary } \\
\text { Secondary/Tertiary }\end{array}$ & $\begin{array}{l}185(92.0) \\
167(83.9)\end{array}$ & $\begin{array}{l}16(8.0) \\
32(16.1)\end{array}$ & 6.244 & $0.012 *$ \\
\hline $\begin{array}{l}\text { Marital status } \\
\text { Currently married } \\
\text { Not currently married }\end{array}$ & $\begin{array}{l}225(92.6) \\
127(80.9) \\
\end{array}$ & $\begin{array}{l}18(7.4) \\
30(19.1)\end{array}$ & 12.366 & $<0.001 *$ \\
\hline $\begin{array}{l}\text { Occupation } \\
\text { Professional \& skilled } \\
\text { Partly skilled } \\
\text { Unskilled }\end{array}$ & $\begin{array}{l}82(95.3) \\
215(84.6) \\
55(91.7) \\
\end{array}$ & $\begin{array}{l}4(4.7) \\
39(15.4) \\
5(8.3) \\
\end{array}$ & 7.868 & $0.020^{*}$ \\
\hline $\begin{array}{l}\text { Monthly income } \\
<\$ 10,000 \\
\geq \$ 10,000\end{array}$ & $\begin{array}{l}241(89.6) \\
111(84.7) \\
\end{array}$ & $\begin{array}{l}28(10.4) \\
20(15.3) \\
\end{array}$ & 1.969 & 0.161 \\
\hline
\end{tabular}

*Statistically significant

Table 7 shows that Islamic religion, lower education, Hausa ethnicity and being currently

married were significantly associated with current use of CAM.

Table7. Respondents' characteristics associated with current use of CAM

\begin{tabular}{|c|c|c|c|c|}
\hline \multirow[t]{2}{*}{ Factors } & \multicolumn{2}{|c|}{$\begin{array}{l}\text { Current use of CAM } \\
N=800\end{array}$} & \multirow[b]{2}{*}{$\chi^{2}$} & \multirow[b]{2}{*}{ p-value } \\
\hline & $\begin{array}{l}\text { Yes } \\
\text { n }(\%)\end{array}$ & $\begin{array}{l}\text { No } \\
\text { n }(\%)\end{array}$ & & \\
\hline $\begin{array}{l}\text { Age } \\
\leq 34 \\
\geq 35 \\
\end{array}$ & $\begin{array}{l}353(79.1) \\
299(84.5) \\
\end{array}$ & $\begin{array}{l}93(20.9) \\
55(15.5)\end{array}$ & 3.698 & 0.054 \\
\hline $\begin{array}{l}\text { Sex } \\
\text { Male } \\
\text { Female }\end{array}$ & $\begin{array}{l}304(81.3) \\
348(81.7)\end{array}$ & $\begin{array}{l}70(18.7) \\
78(18.3)\end{array}$ & 0.022 & 0.882 \\
\hline $\begin{array}{l}\text { Religion } \\
\text { Christianity } \\
\text { Islam }\end{array}$ & $\begin{array}{l}137(69.5) \\
515(85.4)\end{array}$ & $\begin{array}{l}60(30.5) \\
88(14.6)\end{array}$ & 24.782 & $<0.001 *$ \\
\hline $\begin{array}{l}\text { Education } \\
\text { No formal/Primary }\end{array}$ & $308(86.3)$ & 49 (13.7) & & \\
\hline
\end{tabular}


Predictors of Complementary and Alternative Medicine Use by Yoruba and Hausa People in Urban Slum Areas of Ibadan, Nigeria

\begin{tabular}{|c|c|c|c|c|}
\hline Secondary/Tertiary & $344(77.7)$ & $99(22.3)$ & 9.747 & $0.002 *$ \\
\hline $\begin{array}{l}\text { Ethnicity } \\
\text { Yoruba } \\
\text { Hausa }\end{array}$ & $\begin{array}{l}300(75.0) \\
352(88.0)\end{array}$ & $\begin{array}{l}100(25.0) \\
48(12.0)\end{array}$ & 22.418 & $<0.001 *$ \\
\hline $\begin{array}{l}\text { Marital status } \\
\text { Currently married } \\
\text { Not currently married }\end{array}$ & $\begin{array}{l}469(85.4) \\
183(72.9) \\
\end{array}$ & $\begin{array}{l}80(14.6) \\
68(27.1) \\
\end{array}$ & 17.907 & $<0.001 *$ \\
\hline $\begin{array}{l}\text { Occupation } \\
\text { Professional \& skilled } \\
\text { Partly skilled } \\
\text { Unskilled }\end{array}$ & $\begin{array}{l}195(85.5) \\
378(79.1) \\
79(84.0)\end{array}$ & $\begin{array}{l}33(14.5) \\
100(20.9) \\
15(16.0)\end{array}$ & 4.712 & 0.095 \\
\hline $\begin{array}{l}\text { Monthly income } \\
<\$ 10,000 \\
\geq \$ 10,000\end{array}$ & $\begin{array}{l}417(81.1) \\
235(82.2)\end{array}$ & $\begin{array}{l}97(18.9) \\
51(17.8)\end{array}$ & 0.132 & 0.717 \\
\hline
\end{tabular}

*Statistically significant

Table 8 shows odds ratio for predictors of current CAM use, selected independent variable are based on literature review, plausibility of association and association on bivariate analysis. Being currently married had the

highest odds ratio for predicting current use of CAM OR 2.22 (95\% CI 1.458 - 3.390). Other factors were Islamic religion OR 1.631 (95\% CI $1.015-2.622$ ) and Hausa ethnicity OR 1.381 (95\% CI $0.898-2.125)$.

Table8. Predictors of current use of CAM

\begin{tabular}{|c|c|c|c|}
\hline Model & OR & $95 \%$ CI & p-value \\
\hline $\begin{array}{l}\text { Age group } \\
\leq 34 \\
\geq 35\end{array}$ & $\begin{array}{l}1 \\
1.323 \\
\end{array}$ & $0.854-2.048$ & 0.210 \\
\hline $\begin{array}{l}\text { Sex } \\
\text { Male } \\
\text { Female }\end{array}$ & $\begin{array}{l}1 \\
1.381\end{array}$ & $0.898-2.125$ & 0.141 \\
\hline $\begin{array}{l}\text { Religion } \\
\text { Christianity } \\
\text { Islam } \\
\end{array}$ & $\begin{array}{l}1 \\
1.631\end{array}$ & $1.015-2.622$ & $0.043 *$ \\
\hline $\begin{array}{l}\text { Education } \\
\text { No formal/Primary } \\
\text { Secondary/Tertiary }\end{array}$ & $\begin{array}{l}1.355 \\
1 \\
\end{array}$ & $0.884-2.075$ & 0.163 \\
\hline $\begin{array}{l}\text { Ethnicity } \\
\text { Yoruba } \\
\text { Hausa }\end{array}$ & $\begin{array}{l}1 \\
1.381\end{array}$ & $1.000-2.125$ & $<0.001 *$ \\
\hline $\begin{array}{l}\text { Marital status } \\
\text { Currently married } \\
\text { Not currently married }\end{array}$ & $\begin{array}{l}2.22 \\
1 \\
\end{array}$ & $1.458-3.390$ & $<0.001 *$ \\
\hline $\begin{array}{l}\text { Occupation } \\
\text { Professional \& skilled } \\
\text { Partly skilled } \\
\text { Unskilled }\end{array}$ & $\begin{array}{l}1.917 \\
1.972 \\
1\end{array}$ & $\begin{array}{l}1.196-3.075 \\
0.921-4.223\end{array}$ & $\begin{array}{l}0.934 \\
0.081\end{array}$ \\
\hline $\begin{array}{l}\text { Monthly income } \\
<\# 10,000 \\
\geq \$ 10,000\end{array}$ & $\begin{array}{l}1 \\
1.055\end{array}$ & $0.681-1.634$ & 0.810 \\
\hline Constant & 0.179 & & $<0.001$ \\
\hline
\end{tabular}

*Statistically significant

\section{DISCUSSION}

Efficacy was the main reason given by family practice patients in America for using CAM [3]. This is similar to findings of this study as efficacy was the main reason given by Hausa respondents followed by availability, while for Yoruba respondents, the main reason was the belief in the claims of the CAM practitioner followed by efficacy.
Another reason for the use of CAM as reported by this study's respondents was the promotion of health. This was similarly reported by the majority of cancer patients in many European countries who said that they use CAM to increase the body's ability to fight cancer or to improve physical and emotional wellbeing [25]. 
Respondents' sources of information on CAM are similar to results of other studies. These sources of information are the mass media, CAM practitioners, family, friends and hospital staff which were reported by studies done in Lagos [4], Australia [35] and America [12]. On the contrary, other studies in Exeter (United Kingdom), Australia and America reported that the internet and other data bases were important sources of information on CAM [36-38]. This is not surprising since the literacy rate in these developed countries is high and these sources of information are available to the masses, whereas this study was conducted in an urban slum area with lower literacy level and many do not have internet access. Approximately half of the surveyed physicians in America believed in the efficacy of acupuncture, chiropractic and massage and large numbers of them are either referring to or practicing some of the more prominent and well-known forms of CAM and that many physicians believe that these therapies are useful or efficacious [13]. On the contrary, very few respondents in this study reported that they received information about CAM from hospital staff.

Socio-demographic characteristics associated with the use of CAM were higher age, higher income and female gender which is similar to findings of other studies in America [14-16]. Lower-level education was associated with use of CAM in this study which is different from those studies done in America [14-16]. The predictors of CAM use in this study were: being currently married, Islamic religion and Hausa ethnicity establishing that was ethnic disparity in the use of CAM.

\section{REFERENCES}

[1] Umaru FA. Modern and traditional medicine, conflicts and reconciliation. 1st ed. Ibadan: Spectrum books limited; 2006.

[2] Breuner C, Barry P, Kemper K. Alternative medicine use by homeless youth. Arch Pediatr Adolesc Med. 1998; 152: 1071-1075.

[3] Elder NC, Gillcrist A, Minz R. Use of alternative health care by family practice patients. Arch Fam Med. 1997; 6 (2): 181-184.

[4] Kazeem AO, Idowu OS, Olisamedua FN, Ayo $\mathrm{S}$. Use of complementary and alternative medicine for children with chronic conditions in Lagos, Nigeria. 2008; Available from: http// www.biomedcentral.com/1472-6882/8/66.

[5] Oluwatoyin C Amira NUO. Frequency of complementary and alternative medicine utilization in hypertensive patients attending an urban tertiary care centre in Nigeria. BMC Complement Altern Med. 2007; 7 (30).

[6] Ikoh M, Udo AU, Charles AO, Charles JO. The influence of "stock out" on health-seeking behavior of low income women in Uyo urban, Akwa Ibom State, Nigeria. Int Q Community Health Educ. 2008-2009; 29 (3): 257-273.

[7] Idowu E, Mafe MA, Otubanjo OA, Adeneye AK. Herbal remedy in the treatment of malaria: cross sectional survey of residents of Lagos State, Nigeria. Afr J Med Med Sci. 2006; 35 (2): 149-153.

[8] Akenzua GI, Akpovi SU, Ogbeede O. Maternal and child care in rural areas: the role of traditional birth attendants in Bendel State of Nigeria. Journal of Tropical Pediatrics. 1981; 27: 210-214.

[9] Eisenberg DM, Kessler RC, Foster C, Frances E. Norlock FE, Calkins DR, Delbanco TL. Unconventional Medicine in the United States - Prevalence, Costs, and Patterns of Use. N Engl J Med. 1993; 328: 246-252.

[10] Opaleye OO, Adesiji YO, Olowe OA, Fagbami AH. Rabies and anti-rabies immunization in South Western Nigeria: knowledge, attitude and practice. Trop Doct 2006; 36: 116-117.

[11] Robinson A, Cooper S. Trusted information sources: The preferred option for complementary and alternative medicine users. Complementary Health Practice Review. 2007; 12 (2): 120-138.

[12] Clay PG, Glaros AG, Clauson KA. Perceived efficacy, indications, and information sources for medically indigent patients and their healthcare providers regarding dietary supplements The Annals of Pharmacotherapy. 2006; 40 (3): 427-432.

[13] Astin JA, Marie A, Pelletier KR, Hansen E, Haskell WL. A Review of the incorporation of complementary and alternative medicine by mainstream physicians. Arch Intern Med. 1998; 158: 2303-2310.

[14] National Centre for Complementary and Alternative Medicine. The use of Complementary and Alternative Medicine in the United States 2007.

[15] Rajendran PR, Thompson RE, Reich SG. The use of alternative therapies by patients with Parkinson's disease. Neurology. 2001; 57 (5): 790-794.

[16] Tsen LC, Segal S, Pothier MC, Bader AM. Alternative medicine use in presurgical patients. Anesthesiology. 2000; 93 (1): 148-151.

[17] Verhoef MJ, Sutherland LR, Brkich L. Use of alternative medicine by patients attending a gastroenterology clinic. CMAJ. 1990; 142 (2): 121125.

[18] Astin JA. Why patients use alternative medicine, results of a national study. JAMA. 1998; 279 (19): 1548-1553. 
[19] 91. Ottolini MCA, Hamburger EKA, Loprieato JOA, Coleman RHA, Hari C.Â Sachs HCA, Madden RA, Brasseux CA. Complementary and Alternative Medicine Use Among Children in the Washington, DC Area. Academic Pediatrics. 2001; 1 (2): 122-125.

[20] Astin J, Pelletier K, Marie A, Haskell W. Complementary and alternative medicine use among elderly persons: one-year analysis of a Blue Shield Medicare supplement. J Gerontol A Biol Sci Med Sci. 2000; 55 (1): M4-9.

[21] Cherniack E, Senzel R, Pan C. Correlates of use of alternative medicine by the elderly in an urban population. The Journal of Alternative and Complementary Medicine. 2004; 7 (3): 277-280.

[22] Gibson P, Powrie R, Star J. Herbal and alternative medicine use during pregnancy: a cross-sectional survey. Obstetrics \& Gynecology. 2001; 97 (4): S44-S45.

[23] Egede L, Ye X, Zheng D, Silverstein M. The prevalence and pattern of complementary and alternative medicine use in individuals with diabetes. Diabetes Care. 2002; 25 (2): 324-329.

[24] Woodward A, Bullard K, Taylor R, Chatters L, Baser R, Perron B, Jackson J. Complementary and Alternative Medicine for Mental Disorders Among African Americans, Black Caribbeans, and Whites. Psychiatr Serv. 2009; 60: 13421349.

[25] Molassiotis A, Fernadez-Ortega P, Pud D, Ozden G, Scott JA, Panteli V, Margulies A, Browall M, Magri M, Selvekerova S, Madsen E, Milovics L, Bruyns I, Gudmundsdottir G, Hummerston S, Ahmad AMA, Platin N, Kearney N, Patiraki E. Use of complementary and alternative medicine in cancer patients: a European survey. Ann Oncol 2005; 16 (4): 655-663.

[26] MacLennan A, Wilson D, Taylor A. The escalating cost and prevalence of alternative medicine preventive medicine. 2002; 35 (2): 166-173.

[27] Babb DA, Pemba L, Seatlanyane P, Charalambous S, Churchyard GJ, Grant AD. Use of traditional medicine by HIV-infected individuals in South Africa in the era of antiretroviral therapy. Psychol Health Med. 2007; 12 (3): 314-320.
[28] Gold E, Bair Y, Zhang G, Utts J, Greendale GA, Upchurch D, Chyu L, Sternfeld B, Adler S. Cross-sectional analysis of specific complementary and alternative medicine (CAM) use by racial/ethnic group and menopausal status: the Study of Women's Health Across the Nation (SWAN). Menopause 2007; 14 (4): 612-623.

[29] Ezeome E, Anarado AN. Use of complementary and alternative medicine by cancer patients at the University of Nigeria Teaching Hospital, Enugu, Nigeria. BMC Complement Altern Med. 2007; 12 (7): 28.

[30] Sakiru A, William R, Musibau T, Kabiru K, Azeez A. Variations in health-seeking behaviours and attitudes between Fulani herders and Oruba farmers in southwestern Nigeria. Trop Doct. 2007; 37: 184-185.

[31] Amira OC, Okubadejo NU. Frequency of complementary and alternative medicine utilization in hypertensive patients attending an urban tertiary care centre in Nigeria. BMC Complement Altern Med. 2007; 7: 30.

[32] Oyebola D. Some aspects of Yoruba traditional healers and their practice. Trans R Soc Trop Med Hyg. 1980; 74 (3): 318-325.

[33] Kelsey JL, (editor). Methods in observational epidemiology. USA: Oxford University Press; 1996.

[34] World Health Organization. The EPI coverage survey1991.

[35] Robinson A, McGrail M. Disclosure of CAM use to medical practitioners: a review of qualitative and quantitative studies. Complement Ther Med. 2004; 12: 90-98.

[36] Broom A, Tovey P. The role of the Internet in cancer patients' engagement with complementary and alternative treatments. Health (London). 2008; 12 (2): 139-155.

[37] Verhoef MJ, Mulkins A, Carlson LE, Hilsden RJ, Kania A. Assessing the role of evidence in patients' evaluation of complementary therapies: A quality study. Integr Cancer Ther 2007; 6 (4): 345-353.

[38] Schmidt K, Ernst E. Assessing websites on complementary and alternative medicine for cancer. Ann Oncol. 2004; 15 (5): 733-742.

Citation: Chinyerem C. Nwachukwu, et.al. Predictors of Complementary and Alternative Medicine Use by Yoruba and Hausa People in Urban Slum Areas of Ibadan, Nigeria. ARC Journal of Public Health and Community Medicine. 2021; 6(1):22-32. Doi:doi.org/10.20431/2456-0596.0601004.

Copyright: (c) 2021 Authors. This is an open-access article distributed under the terms of the Creative Commons Attribution License, which permits unrestricted use, distribution, and reproduction in any medium, provided the original author and source are credited. 